\title{
Silvofishery as an alternative system of sustainable aquaculture in mororejo village, kendal regency
}

\author{
Woro Kusumaningtyas Perwitasari*, Fuad Muhammad, and Jaffran Wasiq Hidayat \\ Magister Program of Environmental Science, School of Postgraduate, Diponegoro University, \\ Semarang, Indonesia
}

\begin{abstract}
Mororejo village is a village located in a coastal area located in Kaliwungu District, Kendal Regency. Mororejo village has a population of around 4,258 people with $60 \%$ of the population working as fish farmers who use and utilize land near the sea by establishing ponds that are their daily livelihood. Silvofishery is a traditional technology aquaculture model that combines fishery business with mangrove planting, which can increase pond productivity. The purpose of this paper is to find out the silvofishery model that has been applied by coastal communities in Kendal Regency. The application of silvofishery system in Mororejo village is traditional ditch pond, with a range of $80 \%: 20 \%$ mangrove. n. Types of mangrove plants planted are Rhizophora sp and Avicennia sp. Mangroves can function as shrimp aquaculture waste filters (nitrate reduction $44,5 \%$, ammonia $46,6 \%$ and nitrite $59,0 \%$ ) and increase the productivity of shrimp culture (average growth weight 49,833 gr). Socialization and research activities about the benefits of silvofishery for communities in the Kendal regency coast have not been done much but all stakeholders already have a good perception and agreed to apply silvofishery as an alternative system for sustainable aquaculture.
\end{abstract}

Keyword. silvofishery, sustainable aquaculture, pond, mangrove

\section{Introduction}

Coastal area is one of the important economic activities at present. This happens because 80 percent of Indonesia's economic activities are related to this region, including economic activities in the fisheries sector. In addition, most of the populations in the coastal areas have a livelihood by utilizing the natural resources in this area both as rice farmers, fishermen, and pond farmers [1]. Mororejo Village is a village located in a coastal area located in Kaliwungu District, Kendal Regency. Mororejo village has a population of around 4,258 people with $60 \%$ of the population (1,904 inhabitants) working as pond

* Corresponding author: whekhaperwitasari@gmail.com 
farmers who use and utilize land near the sea by establishing ponds that are their daily livelihood [2].

Ponds are one type of habitat that is used as a place for brackish water aquaculture activities located in coastal areas [3]. Ponds found in the village are generally traditional, semi-intensive and intensive in which they grow shrimp and milkfish. The aquaculture area in Mororejo village has an average production potential of up to $500 \mathrm{~kg}$ per ha in a single harvest [2]. Around the pond, there are mangrove plants which have many benefits for the pond such as helping to fertilize the pond, as an abrasion barrier, and also as a natural feed for the cultivation biota in the pond. With the presence of mangroves in the area of the pond is expected to help increase pond production and make farmer income increased. In addition, the right management strategy can help increase pond production so that farmer income will increase.

Rehabilitation of mangrove damage, especially due to the opening of ponds should be our common concern, the local government should be able to better direct community not to damage the mangrove forest. This can be done by inviting the community, especially farmers to participate in carrying out rehabilitation of mangrove ecosystems, these activities can be in the form of the application of silvofishery technology. Silvofishery is a traditional technology aquaculture system that combine fisheries business with mangrove planting, which is followed by the concept of introducing a management system by minimizing inputs and reducing the impact on the environment [4]. This system has been widely recommended for sustainable aquaculture, but the application of this system is still not widely known by farmers as a system that is recommended for pond business activities carried out in mangrove areas or areas designated as protected forests, besides that detailed information abaout the implementation techniques also still not widely known by farmers.

\section{Silvofishery}

Utilization of coastal resources for developing a pond business ideally needs to consider the needs of the community and the preservation of the ecosystem of the mangrove area. In this effort, a pattern of area utilization that is sustainable and environmentally friendly can be developed, namely through the development of silvofishery system. Silvofishery or intercropping ponds, is an agroforestry pattern used in the implementation of social forestry program in densely populated mangrove forests. This pattern is in the form of combination of pond/ponds with mangrove plants (mangrove), which is expected to be abale to improve the welfare of the community on the one hand, and on the other hand to preservation of mangrove areas will be maintaned. This pattern was first applied in Burma, and was succesfull.

Basically the silvofishery principle is an effort to protect mangrove forest areas by providing other results in terms of fisheries. Silvofishery is a technical approach pattern consisting of a series of integrated activities between fish or shrimp farming activities with the activities of planting, maintaining, managing, and conserving mangrove forests. This is understandable because most of the people who live around the mangrove forest area earn a living as fihermen. Thus the intercropping system development, beside being appropriate in terms of ecological condition, is also in harmony with the lifestyle of the surrounding community.

Ponds with silvofishery systems have been developed to increase aquaculture production and protect the area of ponds from damage. Planting or maintaining mangroves can increase the carrying capacity of ponds, so as to maintain water quality and sustain the life of cultivated commodities [5]. Silvofishery aims to optimize profits along with conservation efforts [6]. Silvofishery is a form of cultivation activity with low input that 
integrates mangrove plants in brackish ponds [7]. Pond cultivation with a silvofishery system has been widely applied in Indonesia. The role of mangroves as providers of environmental services is a factor that is expected to support pond aquaculture activities. These services include physical, chemical and biological. The physical role of mangroves for the environment is as sediment trapping [8]. The role of mangrove chemistry is as an absorbent of pollutants, suppliers of organic materials and sources of nutrients[9]. The biological role of mangrove is a spawning area (spawning ground), the area of care (nursery grounds) and the area of foraging (feeding ground) for a variety of aquatic biota[10]. There are various types of plant design variations that develop in the Southeast Asian region [11]. Nevertheless, basically there are only 2 basic forms of silvofishery, namely silvofishery with mangrove arrangements planted inside ponds and silvofishery with mangrove arrangements planted outside ponds. The silvofishery system that is widely applied in Indonesia is a model of a ditch and a pond [12].

\subsection{Trench Empty Pattern}

Silvofishery is an integrated form of activities between brackishwater cultivation and mangrove development in the same location. The silvofishery concept was developed as a form of sustainable aquaculture with low input. The approach between conservation and utilization of mangrove areas makes it possible to maintain the exixtence of mangrove that are ecologically have relativity high productivity with economic benefits form aquaculture activities.

Trench pond pattern is a silvofishery model that is commonly developed by making waterways where fish or shrimp are being cultivated. This water channel surrounds the land used for silvofishery, while mangrove plants can be planted in the middle, so there is a combination of mangrove plants (silvo) and fish cultivation (fishery). This condition can be applied to the area of the former pond to be rehabilitated by utilizing the pond's pond (the middle part) to be planted with mangroves, while the caren or trenches are left as before. By using this ditch pond system, the land to be reforested can reach around $80 \%$ of the pond area. Mangrove planting can be done with a spacing of 1 x 1 meter between individual mangroves [13].

The density of mangroves will affect the aquaculture system, because the productivity of silvofishery ponds is highly dependent on organic materials derived from mangrove litter. Low vegetation density is suitable for milkfish ponds, while higher vegetation density is suitable for shrimp and mangrove crab cultivation. Mangrove species that are generally planted are mangroves (Rhizophora $s p$ ) or can also use a type of fires (Avicennia spp).

\subsection{Complex Model}

The model or pattern of the plot is a silvofishery system with a pond design alternating adjacent to the land to be planted with mangove. The fields for mangrove and ponds are separated in two fields arranged by waterways with two separate sluice gates. The area that will be used used for silvofishery with this model is suggested to be between 2-4 ha, so a standard pond size will be developed to maintain fish / shrimp at least 1 ha. This model is a method of brackish water cultivation with low input and produces minimal negative impact on the environment (ecosystem).

The integrated system applied perpendicular to the coastline allows a number of freshwater flows to reach the mangroves in the greenbelt area. This model can also maintain an abundance of biodiversity. In practice, the silvofishery of this partnership model is more suitable to be applied in areas with clear ownership, such as government- 
owned land or lands owned by community groups. Technical management recommendation from the activities of silvofishery covering three areas, namely: shrimp culture, silviculture in mangroves and aquaculture diversification are provided [14]. In addition recommendations are made on studies in the economic, social and policy development issues. For improvements to shrimp farming activities, recommendations are focused on improving water quality and sediment quality, stock techniques for tiger shrimp seeds, and wild shrimp stocks and harvesting techniques.

Several things to consider in the design of silvofishery ponds [15], are as follows :

a. The ratio between the mangrove area and the pool water area

b. The ratio between the water area and the length of the pond embankment

(shows the area of production area with the value of investment costs)

c. The ratio of the width of the door to enter natural seeds and pond flushing $(50 \mathrm{~cm} / \mathrm{ha})$

d. Tidal flushing rate and tidal flushing range

e. Drain water in the pond when the water is stagnant, i.e low oxygen level

occur, especially in the bottom of the water

f. The length and width of the channel and,

g. Position of location, state of land, abundance of natural stocks

\section{Methodology}

\subsection{Time and place}

This research was carried out in Mororejo Village, Kendal Regency. The research period is 4 months, from January 2020 to April 2020.

\subsection{Material and tools}

Data collected in this study include primary and secondary data, primary data is data taken directly at the time of the study, through observation, questionnaires, and direct interviews at the research location. Secondary data was obtained from a number of related institutions, namely the Environmental Forestry Office and Kendal Regency's Fisheries and Maritime Affairs Office, and supporting references in this study.

\subsection{Method of collecting data}

\subsubsection{Pond area biotechnology data}

Sampling for the biotechnical conditions of the pond area is done by purposive sampling method, namely the method of sampling is not random but based on consideration of the type and utilization according to the objectives and conditions in the field, and is considered representative. This data is very useful for the preparation of a silvofishery system that will be applied, interviews conducted with farmers, fishers and collectors. Data taken includes the design and construction of ponds, cultivation technology, catches in mangrove areas, and water quality conditions. 


\subsubsection{Socio-economic data}

The collection of socioeconomic data in this study uses the method of interviews, discussions and questionnaires. Interviews and discussions were conducted with farmers, communities, protected area managers and related institutions. Interviews and questionnaires were conducted with farmers, followed by in-depth interviews with local figures. The questionnaire was given to 40 farmers who carried out aquaculture business on the pond, so it was hoped that they could provide a detailed description of the condition of the business activities they carried out. Interviews with the government will be chosen based on their position and involvement in the management of protected areas. Determination of respondents for socioeconomic data using purposive sampling method.

\subsection{Data analysis}

\subsubsection{Biotechnical condition analysis}

Biotechnical analysis is carried out by analyzing regional biotechnical data on traditional pond activities currently carried out, with reference to: Guidelines relating to environmental management and the standard stages of aquaculture activities in ponds, silvofishery technology and water quality. Furthermore, making a technical plan for the application of silvofishery which includes: Arranging the layout of the area, preparing construction designs and making appropriate cultivation technology procedures. Research on production optimization while integrating mangroves and aquaculture must be a priority. The research carried out must lead to increased production of various silvofishery models. Another important thing is reforestation activities on lands that have become privately owned. The intended optimization is the use of production inputs and strategies for spreading different species in the polyculture production system [16].

\subsubsection{Analysis of farmers perception}

Perceptual analysis used to determine the community's view of mangrove ecosystem management in Mororejo village was carried out by submitting interviews and questionnaires to 50 farmers, while other stakeholders were conducted with in-depth interview techniques. So as to know the conditions, knowledge, motivation and social acceptance of farmers and stakeholder support in determining the stages of silvovofishery application.

In the strategy of implementing silvofishery, a very crucial part in the success of the management of the area is the farmers, area managers and related institutions. The institution is very concerned with the conditions and potential of existing natural resources in the mangrove ecosystem. So that the conditions and activities of these stakeholders around the mangrove area will have an impact on the mangrove ecosystem, or in other words the success of mangrove management based on silvofishery is highly dependent on the perceptions and participation of all stakeholders. Farmers 'perceptions are measured by quantitative values in terms of the percentage of farmers' views on mangrove ecosystem management in Mororejo village, which ranges from $0 \%$ to $100 \%$ which shows very poor views $(0 \%)$ to very good $(100 \%)$. Whereas perceptions of area managers and related institutions are carried out by in-depth interviews with competent parties. Conditions and farmers' perceptions of silvofihsery in Mororejo village are divided into 3 (three) question groups, including:

1) Condition of pond business activities and protected forest status (4 questions) 
2) Business motivation and environmental awareness (7 questions)

3) Farmer's knowledge and motivation on the application of silvofishery (5 questions). The answers from the respondents are then analyzed using a rating scale, which is the total number of interviews divided by the number of criterion scores (highest score $\mathrm{x}$ number of questions $\mathrm{x}$ number of respondents) and then multiply by 100 to get the percentage. Value level categories $(\mathrm{N})$ given in the results of mangrove ecosystem management interviews in

Mororejo Village are as follows:

- $80<\mathrm{N} \leq 100 \%=$ Very Good, with a value of 5

- $60<\mathrm{N} \leq 80 \%=$ Good, with a value of 4

- $40<\mathrm{N} \leq 60 \%=$ Medium, with a value of 3

- $20<\mathrm{N} \leq 40 \%=$ Poor, with a value of 2

- $0<\mathrm{N} \leq 20 \%=$ Not good, with a value of 1

\section{Result and Discussion}

\subsection{Silvofishery pond model and productivity}

Silvofishery pond model that will be developed, must be adapted to the condition of the location of the activity, especially if there are already existing pond activities in the area. Rehabilitation activities at the existing pond location including comparison of the percentage of mangrove-ponds must be flexible and accommodative to be more easily accepted by the farmers, especially in the initial phases of rehabilitation activities. The selection of the right silvofishery pond model is highly dependent and will be influenced by the status of the mangrove ecosystem, so there is no one model that can be said to be most appropriate in all situations [16]. The development of the silvofishery model must be integrated into a broader range of approaches in a coastal area management system. The pattern of integration of conservation and utilization of mangrove resources, leads to the best management conditions of mangrove resources, that is when the economic benefit value obtained from the cultivation business activities carried out.

Based on the consideration of the management of mangrove ecosystems and cultivation technology applied in the area mentioned above, it can be stated that through the biotechnical conditions of each of the approach models, the most likely is the traditional trench pond model. Because by applying this model there is almost no difference from the existing pond model, only in silvofishery system ponds, this model farmers not only rely on ponds as the backbone of increasing people's income, but also can obtain economic benefits from the mangrove forest ecosystem itself. For regular ponds, mangrove planting can be carried out on the side of the pond embankment or in the supply and embankment dikes which are still affected by tides. So that the cost of pond reconstruction can be done at a low cost and can be immediately applied to existing traditional ponds. There is great potential to restore the loss of mangroves through the application of basic ecological principles, restoration using an ecological engineering approach including careful evaluation of costs in the design and construction [17]. It was previously known that efforts to restore mangroves, success was largely concentrated on planting mangroves with only a few species, and when targeted for harvest as wood products, or temporarily used to collect sediment soils and enhance intertidal areas to be used as terrestrial agriculture. The increase in construction costs will also not occur, because with conventional ponds that exist today there is no additional cost needed to make a mound in the middle of the pond as a place to grow mangroves. 


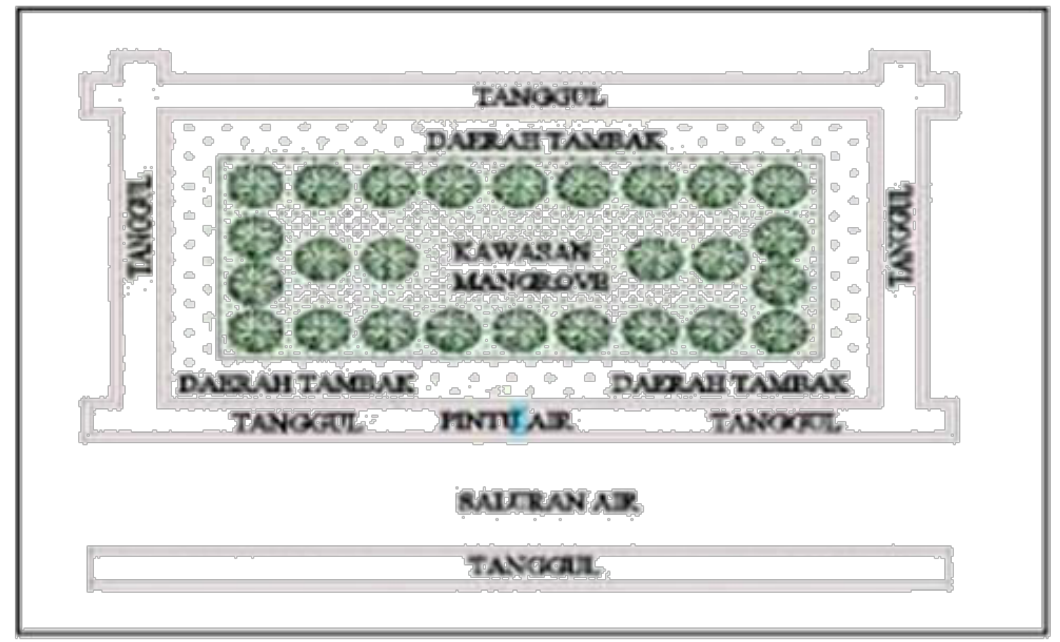

Fig.1. Design of silvofishery pond

In the traditional ditch pond model, mangrove growing areas and shrimp / fish nurseries are in one stretch. Water management is regulated through a single door that connects the expanse to the water channel. The advantage of this model lies in its very simple design so that the investment needed to build a pond is quite small. The advantage of mangroves is that mangroves can function as shrimp aquaculture waste filters, with the presence of mangrove ecosystems the value of nitrate reduction is $44.5 \%$ ammonia $46.6 \%$ and nitrite $59.0 \%$ from shrimp waste[18]. The ratio of mangrove area needed to absorb organic waste from intensive shrimp farming activities is $1: 14$.

Selection of the right type of mangrove and mangrove density regulation can reduce the negative impacts, so that pests that are feared will be reduced, sunlight will be enough to illuminate the pond and water productivity can be maintained. Mangrove litter which has been considered as a problem, apparently based on several studies is a source of nutrients for the fertility of the waters itself, especially from Avicennia $s p$. The bacteria in sediments have been known as important food for invertebrates, which form the basis of food webs in benthic ecosystems. This trophic role has been well documented, but the role of bacteria plays an important role as decomposers of detritus and recycling of essential nutrients [19]. Final evidence suggests that the more important role of bacterial trophic function is in tropical mangroves and sediments in coastal areas. What is considered a weakness is pond water ponds become one with mangrove growing areas, cultivation efforts cannot be carried out ideally.

Silvofishery system can increase the productivity of tiger shrimp cultivation (Penaeus monodon). The growth rate of shrimp length that is cultivated in silvofishery ponds with Rhizophora vegetation is $6.767 \mathrm{~cm}$, while the average growth weight reaches $49.833 \mathrm{~g}$ [20]. Aquaculture ponds with silvofishery systems provide higher profits compared to ordinary ponds. Integration of mangrove vegetation in aquaculture shows a positive effect on shrimp farming. This is indicated by a higher growth rate compared to ponds without mangroves[21]. The production of tiger shrimp in pond 1 (the density of mangroves in pond 1 is greater than in pond 2) which is $42 \mathrm{~kg} / 5$ months (size 26) and in pond 2 is $29 \mathrm{~kg}$ / 5 months (size 26) [22]. This happens because the greater density can increase the amount of natural feed that enters the ponds derived from leaf litter, stems and mangrove seeds that can be utilized by shrimp. The density of trees affects the amount of organic waste that enters the pond. The smaller density is suitable for fish farming, while the higher density is 
suitable for shrimp or mangrove crab cultivation [23]. Rhizophora mucronata has better resistance to pollution compared to Avicennia marina [24]. Rhizophora mucronata produces tannins from mangrove leaves. Tannins function in maintaining the availability of nitrogen as a buffer cycle of nutrients in the mangrove ecosystem [25]. Thus, the nutrient content in ponds with Rhizophora vegetation tends to have more abundant nutrient content compared to Avicennia. Tannin also contains a lot of protein which is gradually released into the aquatic environment during the daytime.

Silvofishery as an integrated business concept between mangrove forest and aquaculture that is aquaculture in a pond becomes a prospective business alternative and is in line with the principle of blue economy[26]. An integrated approach to conservation and utilization of mangrove forest resources provides an opportunity to maintain a good condition of the forest area, in addition, brackish water cultivation can produce economic benefits. The most important thing is that this concept offers applicative technology alternatives based on the principle of sustainability. Integrated management of pond mangrove is realized in the form of a fisheries cultivation system that includes mangrove trees as part of a cultivation system known as silvofishery. Silvofishery is basically a protection of mangrove areas by making ponds in the form of channels which are both capable of symbiosis so that ecological and economic benefits are obtained because they consider ecological care (ecological awareness).

The function of mangroves as a nursery ground is often used for the benefit of fisheries development. A double benefit has been obtained from this symbiosis. In addition to the decent fisheries, the maintenance costs are also cheap, because without having to provide food every day. This is because the production of phytoplankton as the main energy of the waters has been able to meet the needs for aquaculture ponds. So, silvofishery system can be applied as an alternative form for sustainable aquaculture.

\subsection{Farmer's perception}

As we know that in the management of mangrove ecosystems a very decisive part in the sustainability of the management of the area is the local community, especially farmers, this is because the local community is very dependent on the conditions and potential of natural resources in the mangrove ecosystem. So that community activities around the mangrove area will have an impact on the mangrove ecosystem, or in other words the good and bad management of mangroves depends on community participation. The percentage value of community views on the management of mangrove ecosystems and the perception of the application of silvofishery in Mororejo village ranged from $0 \%$ to $100 \%$ which shows very poor views $(0 \%)$ to very good $(100 \%)$. Based on the results of interviews and questionnaires with 40 farmers, the level of farmers' perceptions of silvofishery application in Mororejo village. This can be described from the results of the interviews in each group of questions as follows:

Table 1.Conditions of pond business activities and forest protection status

\begin{tabular}{|c|l|c|}
\hline No & Condition and perception & Percentage (\%) \\
\hline 1 & Recent condition of pond activities & 31,0 \\
\hline 2 & Guidance and government assistance & 23,0 \\
\hline 3 & $\begin{array}{l}\text { Socialization about the determination of } \\
\text { mangrove protected forest areas }\end{array}$ & 23,0 \\
\hline 4 & $\begin{array}{l}\text { Clarity of legal status between farmers and } \\
\text { area managers }\end{array}$ & 23,0 \\
\hline & Average & 25,0 \\
\hline
\end{tabular}


Guidance and government assistance to the current pond business activities are currently in a bad condition. Likewise, information and socialization about the determination of mangrove protected forest areas conveyed by related institutions according to the farmers was conveyed by methods that were not good. Government institutions which are authorized in the management of mangrove ecosystems have so far been deemed to have not carried out their functions properly. This can be seen from the absence of conservation and mangrove ecosystem management activities carried out by government agencies. Development activities and community economic empowerment have also never been carried out by the relevant government agencies. In fact, according to the community, government institutions have never done any socialization about establishing mangrove protected areas in their villages. In addition, policies and coordination between agencies involved in managing mangroves also overlap and contradict each other. This can be seen from the existence of policies and farm business permits in protected areas issued by the Kendal Regency Maritime and Fisheries Office at that time, these licenses should have been coordinated with the area manager, namely the Forest Service.

Table 2. Effortness motivation and environmental awareness

\begin{tabular}{|c|l|c|}
\hline No & Condition and perception & Percentage (\%) \\
\hline 1 & Motivation in continuing the business & 89,0 \\
\hline 2 & Influence on pond business activities & 97,5 \\
\hline 3 & The ponds activities will be rediscussed & 97,5 \\
\hline 4 & Farmers are given permission based on agreement & 97,5 \\
\hline 5 & Undestuctive technology (environmentally friendly) & 97,5 \\
\hline 6 & Improvement efforts (rehabilitation) & 97,5 \\
\hline 7 & $\begin{array}{l}\text { The effect of environmental quality conditions on } \\
\text { production }\end{array}$ & 97,5 \\
\hline & Average & 96,3 \\
\hline
\end{tabular}

The commitment to protect the environment also approves, namely by agreeing to the farm's activities with technology that does not damage the environment. Pond production activities also improve by repairing the repair of damaged environments including what they agree on. The environment increases the quality of the environment that is getting better (sustainable) towards increasing the production of ponds is very good.

Table 3. Knowledge and motivation for the application of silvofishery

\begin{tabular}{|c|l|c|}
\hline No & Condition and perception & Percentage (\%) \\
\hline 1 & Knowledge about silvofishery & 27,5 \\
\hline 2 & curiosity about silvofishery & 97,5 \\
\hline 3 & Silvofishery as an agreement & 97,5 \\
\hline 4 & Expectations of the role of the government & 97,5 \\
\hline 5 & Motivation to apply silvofishery & 97,5 \\
\hline & Rata-Rata & 80,0 \\
\hline
\end{tabular}

From the results of interviews and questionnaires with the interest of farmers to implement the silvofishery system as a pond activity recommended by the government is very good. Especially with the current conditions the application of this system is the most possible solution. 


\section{Conclusions}

Revitalization of the ponds with the application of the silvofishery system is very appropriate to be carried out at the study site, namely the traditional ditch pond model, because it is in accordance with the existing farm biotechnical conditions. With the application of this model a range of $80 \%$ : $20 \%$ mangrove can be generated between the mangroves and ponds so that mangrove rehabilitation of 444.28 hectares will be achieved. All stakeholders in the mangrove area in Mororejo village already have a very good perception and agreed to maintain the sustainability of the mangrove ecosystem and apply a silvofishery as an alternative system for sustainable aquaculture.

\section{References}

1. R. Dahuri, J. Rais, S.P. Ginting, M.J. Sitepu. Pengelolaan sumberdaya wilayah pesisir dan lautan secara terpadu. Pt. Pradnya Paramita. Jakarta (1995)

2. A. Kridalaksana, Subiyanto, A. Suryanto. Pengelolaan tambak dan mangrove di area pertambakan di desa mororejo, kecamatan kaliwungu, kendal. Diponegoro Journal of Maquares (Mangement of Aquatic Resources) vol. 3 no.2 : 148-156 (2014)

3. M.N. Suparjo. Daya dukung lingkungan perairan tambak desa mororejo kabupaten kendal. Jurnal Saintek Perikanan Vol. 4, No. 1 :50-55 (2008)

4. M.I. Shilman. Kajian penerapan wanamina untuk rehabilitasi ekosistem mangrove desa dabong kecamatan kubu kabupaten kubu raya provinsi kalimantan barat. Tesis Program Pasca Sarjana Institut Pertanian Bogor (2012)

5. I. Sualia, B.P. Eko, I.N.N Suryadiputra. Panduan pengelolaan budidaya tambak ramah lingkungandi daerah mangrove. Wetlands International Indonesia Programme. Bogor (2010)

6. J.H. Primavera. Integrated mangrove-aquaculture systems in asia. Integrated Coastal Zone Management Autumn:121-128 (2000)

7. S.R. Bush, P.A.M.van Zwieten, L.Visser, H. van Dijk, R. Bosma, W.F de Boer, M. Verdegen. Scenarios for resilient shrimp aquaculture in tropical coastal areas. Ecology and Society 15(2):15 (2010)

8. Pramudji. Mangrove di pesisir delta mahakam timur. Pusat Penelitian Oseanografi LIPI. Jakarta (2004)

9. Pramudji. Kajian hutan mangrove di kawasan pesisir kabupaten penajam, kalimantan timur. Laporan Penelitian Pusat Penelitian Oseanografi LIPI, Jakarta (2002)

10. Supriharyono. Konservasi ekosistem sumberdaya hayati. Pustaka Pelajar, Yogyakarta (2009)

11. J.W. Fitzgerald. Silvofisheries :integrated mangrove forest aquaculture systems in B.A. Costa-Pierce(editor). Ecological Aquaculture : The Evolution of a Blue Revolution. Blackwell Science Ltd, Oxford, UK (2002)

12. P. Santoso, Sunadji, Yahyah. Penerapan teknologi tambak wanamina sebagai implementasi pengelolaan ekosistem mangrove secara lestari di desa oebelo. Perancangan dan Kaji Tindak 16 : 15-23 (2010)

13. D.G. Bengen. Pengenalan dan pengelolaan ekosistem mangrove. PKSPL, IPB, Bogor (2002)

14. B. Clough, D. Johnston. Silvofishery farming system in ca mau province, vietnam. Australian Institute of Marine Science, Queensland, Australia (FAO, WWF, and NACA) (2002)

15. J.W. Fitzgerald, J.Jr. William. Integrated mangrove forest and aquaculture system (silvofisheries) in Indonesia. Food and Agricultural Organization of the United 
Nations (FAO), the World Bank Group, World Wildlife Fund (WWF) and the Networl of Aquaculture Centres in Asia-Pacific (NACA) (2002)

16. D.J. Macintosh, E.C. Ashton, S. Havanon. Mangrove rehabilitation and intertidal biodiversity : a study in ranong mangrove ecosystem, thailand. Estuarine, Coastal and Shelf Science 55:331-345 (2002)

17. R.R. Lewis III. Ecological engineering for successful management and restoration of mangrove forests. Ecological Engineering 24 : 403-418 (2005).

18. N. Fancy. The potential of mangrove in the treatment of shrimp aquaculture effluent on the eastern coast of thailand (a thesis). Departement of Geography, University of Victoria (2004)

19. D.M. Alongi. The role of bacteria in nutrient recycling in tropical mangrove and other coastal benthic ecosystems. Hydrobiologia 285 :19-32 (1994)

F. J. Manson, N. R. Loneragan, G.A. Skilleter, S.R.Phinn. An evaluation of the evidence for linkages between mangroves and fisheries: a syhthesis of the literature and identification of research directions. Oceanography and Marine Biology:an Annual Review 43 : 485-515 (2005)

20. R. Budiastuti. Pengaruh penerapan wanamina terhadap kualitas lingkungan dan pertumbuhan udang di kota semarang. Prosiding Seminar Nasional Pengelolaan Sumberdaya Alam dan Lingkungan. ISBN 978-602-17001-1-2

21. S. Mardiyati. Optimasi usahatani tumpangsari empang parit di lahan konservasi hutan mangrove RPH cikiperan BKPH rawa timur KPH banyumas barat. Tesis, Program Pasca Sarjana UGM (2004)

22. Z. Syam, Yunasfi, M. Dalimunthe. Pengaruh hutan mangrove terhadap produksi udang windu (Penaeus monodon) pada tambak wanamina di desa tanjung ibus kecamatan secanggang kabuaten langkat. Jurnal Aquacoastmarine, 2(1):107-117 (2014)

23. N. Harahab. Penilaian ekonomi ekosistem hutan mangrove dan aplikasinya dalam perencanaan wilayah pesisir. Graha Ilmu, Yogyakarta (2010)

24. W. Ahmed, S.S. Shaukat. Effect of heavy metal pollution on leaf litter decompotion of two species of mangrove, Avicennia marina and Rhizopora mucronata. Journal of Basic and Apllied Science 8 : 696-701 (2012)

25. N. Maei, O. Pisani, R. Jafee. Manggrove tannins in aquatic ecosystems:their fate and possible influence on dissolved organic carbon and nitrogen cycling. Limnol Oceanogr. 53(1) :160-171 (2008)

26. Kementerian Kelautan dan Perikanan, Direktorat Jenderal Perikanan Budidaya. Budidaya wanamina, budidaya berdasarkan prinsip keseimbangan. http://djpb.kkp.go.id/berita.php?id=839 (2013) 